\title{
sciendo
}

\section{Twitter usage in Tourism: Literature Review}

\author{
Tamara Ćurlin \\ The University of Zagreb, Faculty of Economics and Business, Zagreb, Croatia \\ Božidar Jaković \\ The University of Zagreb, Faculty of Economics and Business, Zagreb, Croatia \\ Ivan Miloloža \\ The University of Osijek, Faculty for Dental Medicine \& Health, Osijek, Croatia
}

\section{Abstract}

Background: Twitter is the most popular microblog platform. Individuals, companies, organizations, and even governments use Twitter on a daily bases and get vast benefits from it. Twitter also has been valuable for the tourism sector, especially in developing business strategies, planning and studying tourist decision-making processes. Objectives: Goal of the paper is to identify the trends, patterns and the research gaps of the research focusing on the Twitter usage in tourism. Methods/Approach: A bibliometric analysis was conducted in order to identify significant authors, journals, and institutions who engaged in the research-oriented towards Twitter utilization in tourism. In addition, text-mining analysis has been conducted in order to extract and identify the topics of the papers investigating the utilization of Twitter for tourism research. Results: Research of Twitter utilization in tourism has increased substantially in the last decade, with most of the research conducted in the United States and Japan. Extracted topics are focused on distinctive themes, such as network analysis, word of mouth, and destination management. Conclusions: New topics have emerged, such as the utilization of Twitter in crisis communication and terrorist attacks, as well as the integration of Twitter and other social media such as Flickr.

Keywords: Twitter, tourism, social media, bibliometric analysis, text mining JEL classification: $\mathrm{O} 33$

Paper type: Research paper

Received: Dec 05, 2018

Accepted: Feb 28, 2019

Citation: Ćurlin, T., Jaković, B., Miloloža, I. (2019), "Twitter usage in Tourism: Literature Review" Business Systems Research, Vol. 10 No. 1, pp.102-119.

DOI: 10.2478/bsrj-2019-0008

\section{Introduction}

Social networks, microblogs, and e-WoM became integral parts of our everyday life. Their influence is significant, both for personal aspect and for business. The use of social networks is leading individuals and businesses towards a new era for the global economy (Trusov et al., 2009).

Social media has become omnipresent. Statista (2018) predicts that within a period of three years, a third of Earth's entire population will actively use it. According to Wells (2011), the term "social networking" cannot be revised without alongside the term 
"social media." Social networks are considered as platforms which focuses on the relationship between people who share mutual interests, connections and activities, while social media are determined as means of communication, which provides people to reach and influence others. Social networks are part of social media, and they are both parts of viral marketing (Gutiérrez et al., 2017).

Influence of social networking, e-WoM, and microblogs for travel planning and exchanging experiences has been researched as an emerging topic. Tung et al. (2011) revealed that tourists share more than just their knowledge; they share experiences, which are considered as the personal evaluation of events in the whole travel cycle. Social media posts before, after and during the tourism traveling include imaginations, emotions, and feelings about destination and experience (Baym, 2015).

Munar et al. (2013) acknowledge that advice on practical implications and embodied feelings are significant in internet reviews. Therefore, social networks and other social media in tourism provide a vast amount of information that is useful for decision-making, information search, and promotion of tourist destinations, products, and suppliers. According to TripAdvisor's Trip Barometer (2014), nearly $90 \%$ of travelers worldwide take into account online reviews while choosing their trip. In fact, more than half of travelers are willing to change (Amaro et al., 2016). Social media in travel context is used differently worldwide. For instance, travelers from the UK use social media as the primary resource when planning their holiday (World Travel Market, 2013). On the other hand, in the Asia-Pacific region, $44 \%$ of leisure travelers use social media platforms for advice and inspiration when choosing holiday destinations (eMarketer, 2013; Uşaklı et al., 2017).

Twitter is one of the top ten most visited websites, and it is considered the most popular microblogging site in the world (Antoniadis et al., 2015; Philander et al., 2016). According to Kirilenko et al. (2014), over a half billion retweets per day have been recorded. Gonçalves et al. (2011) stress the value of Twitter data and metadata for the interpretation of users' communication and behavior. Deddens (2011) points out that the original purpose of Twitter was informing what people do. However, Twitter has become one of the most important information channels about current personal and public events (Tenkanen et al., 2017).

According to Kwak et al. (2010), the prevalence of Twitter generated significant implications for hospitality and tourism. Twitter is one of the top three platforms that are the most often used by US hotels and restaurant operators (Kim et al., 2013). Twitter can also be useful for examining the electronic word of mouth. Twitter allows the tourism sector subjects to gather qualitative feedback or establish competitive benchmarks (Xiang et al., 2015).

Tourism is one of the industries that has gained vast benefits from social networks, specifically in tourist behavior observing, planning and developing marketing strategies (Zeng et al., 2014). Numerous studies examined the impact of social network and e-WoM on tourism (e.g., Leung et al., 2013; Zeng et al., 2014; Law et al., 2018). However, most of the research focused on Facebook, e.g., as the example of a social network used in a destination or for tourism planning (Bruhn et al., 2012). To our best knowledge, there is no bibliometric analysis conducted using a systematic literature review that would focus on the utilization of Twitter in tourism. The first goal of our research is to conduct a bibliometric analysis with the goal to identify the most prominent authors, institutions, as well as the most influential papers in terms of citations. The second goal of the paper is to investigate topics of the papers, using text mining. 
This paper consists of four sections. After the introduction section, the methodology section demonstrates the methods and tools used to carry out this paper: systematic literature review and text mining. In the results section, the outcomes of systematic literature review and text mining are presented and interpreted. Systematic literature review revealed the publication trends according to the timeline, citations, countries and the research areas. Text mining revealed the most common words and phrases mentioned in the paper abstracts. In order to extract topics of the research, cluster analysis has been used. Six themes were extracted. Finally, the conclusion of the paper points out the main results of our research and future research directions.

\section{Methodology}

Systematic Literature Review

A systematic literature review has been conducted based on Preferred Reporting Items for Systematic Reviews and Meta-Analysis (PRISMA) standard (Moher et al., 2016), using the Scopus database, as one of the most authoritative citations databases (Gasparyan et al., 2011).

We searched Scopus using the search phrase "Twitter" AND "Touris*". Total of 226 papers was extracted in the first phase. In order to exclude papers irrelevant to the given theme, authors have read the full text of the papers and remove papers that are not related or are ambiguously related to the research topic. Therefore, the list of 46 papers which are the focus of this research was finalized.

Appendix 1 provides a list of papers included in the bibliometric review. A bibliometric analysis was carried out, classifying papers according to the year of publication, journals, organizations, countries, and authors.

\section{Text mining}

Text mining aims to analyze textual document in order to extract data, transform it into information and make it useful for various types of decision-making (Gupta et al., 2009). Words and phrase frequencies were extracted, as well as the proximity between phrases between the number of different articles. Finally, the proximity between phrases within the documents was the base for developing cluster analysis. For the purpose of text mining, we used WordStat Provalis 8.9.

Firstly, the most prevalent words with a frequency of ten or higher in the documents were extracted. Furthermore, phrases with a maximum of five words, which appear in more than three paper abstracts were extracted. Cluster analysis of phrases was conducted using the average-linkage hierarchical clustering algorithm (Everitt et al., 2011). The distance between two clusters represents the medium distance between each observation in one cluster to every observation in the other, called Unweighted Pair Group Mean Averaging (Wiggerts, 1997).

Jaccard's coefficient as a similarity measure was used to perform cluster analysis in order to determine the association between two phrases that appear at the same time. A dendrogram represents the result. Dendrogram determines only the temporal order of the branching sequence; the sequence of phrases cannot be seen as a linear representation of those distances (Pejić Bach et al., 2019). That means that any cluster can be rotated around branches on the dendrogram without affecting its meaning. Because of that reason, proximity plot was used which was generated in WordStat Provalis software to represent the distance between most common phrases to all other phrases. 


\section{Results}

\section{Systematic literature review}

By searching the Scopus database, using the keywords "Twitter" and "Tourism," we found 46 documents altogether. Figure 1 presents the timeline of the papers published on these topics.

Figure 1

Number of papers related to Twitter and tourism

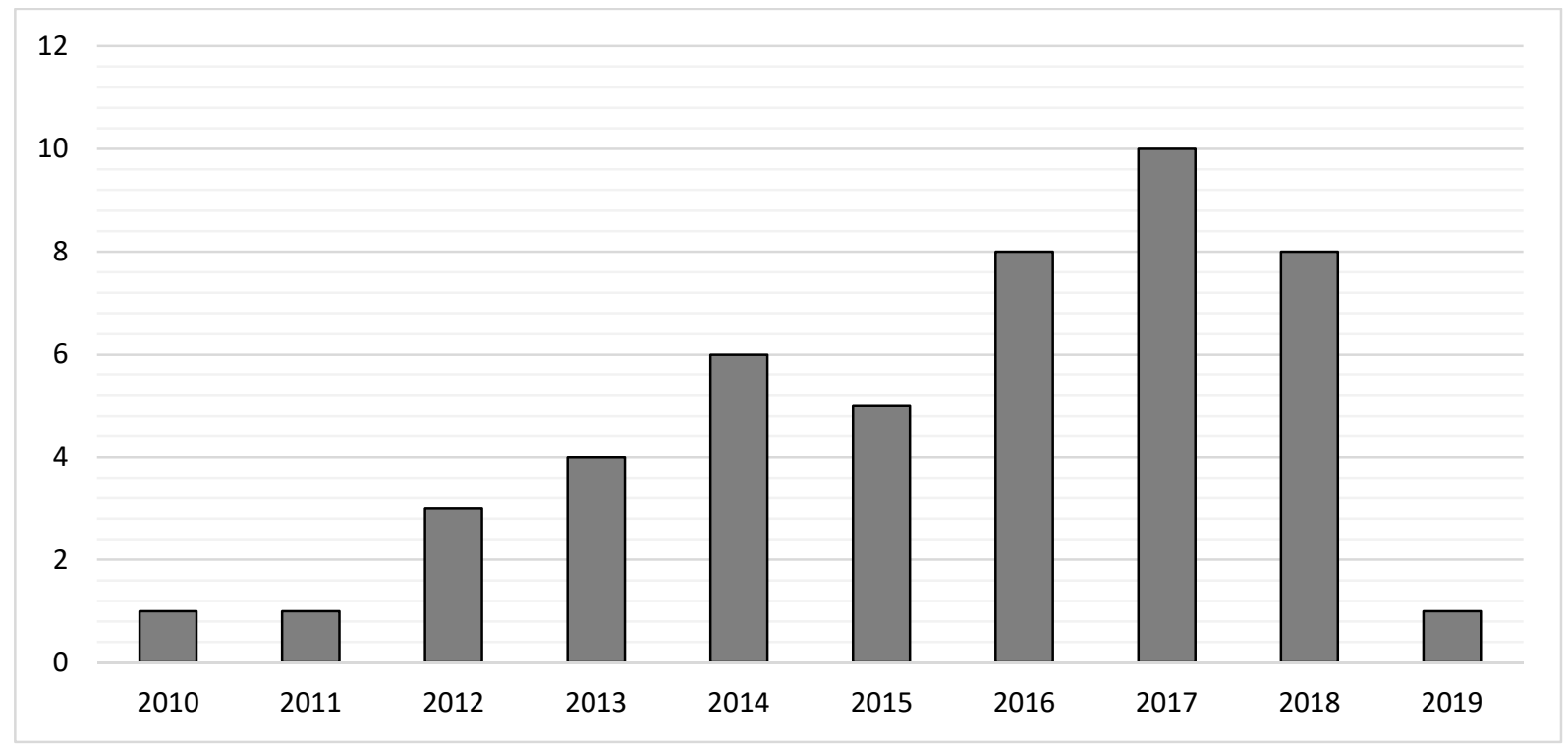

Source: Authors' work, based on Scopus systematic literature review

The first research study on the topic was published in 2010, and within the first four years, the number of researches was scarce. Noticeable interest on the topic emerged in the last few years, with the constant outcome for the last three years between 8-10 papers per year.

As for the research area, two categories emanate as most relevant with $30 \%$ documents in each category (see Figure 2.): "Business; Management and Accounting" and "Computer Science". As regarding for other areas, $17 \%$ of documents were found in "Social Science", 3\% within the "Mathematics" category and "Economics; Econometrics and Finance" category. Other fields were represented within only $1 \%$ of documents.

These results suggest that the interest on the topic is omnipresent, with the center focus on the aspects of business management and computer science. Alongside, suggested aspects represent the core of the subject. However, it is interesting to see that the scopes as econometrics and mathematics also have their interest in a topic which confirms a trend that various methods and mathematic tools are used to manage and data from the Twitter in the tourism industry. 
Figure 2

Area of research of papers related to Twitter and tourism
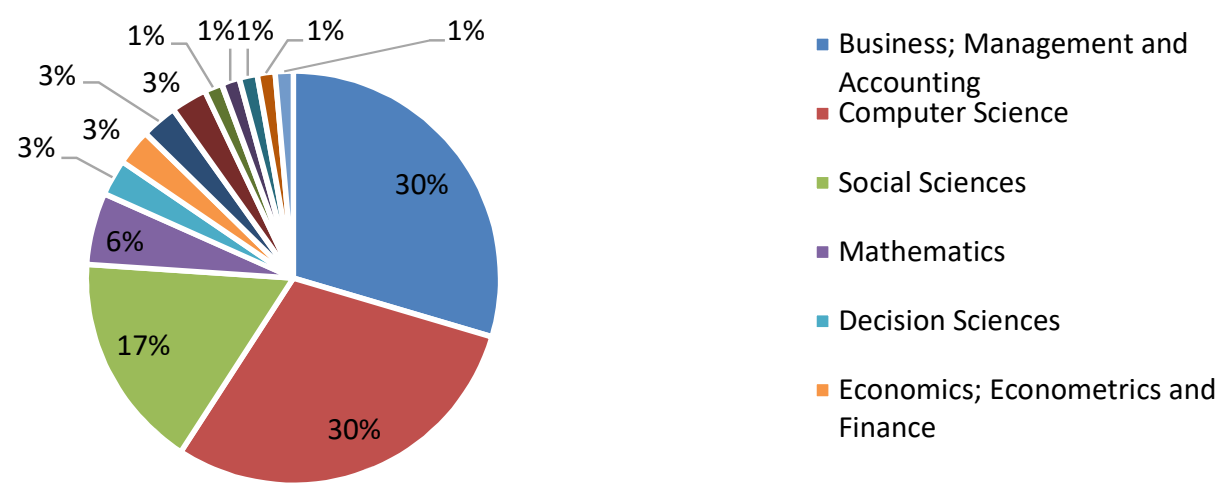

Source: Authors' work, based on Scopus systematic literature review

The number of citations substantiates the trend for the number of papers conducted on the topic by year (Figure 3).

Figure 3

Number of citations of the papers related to Twitter and tourism

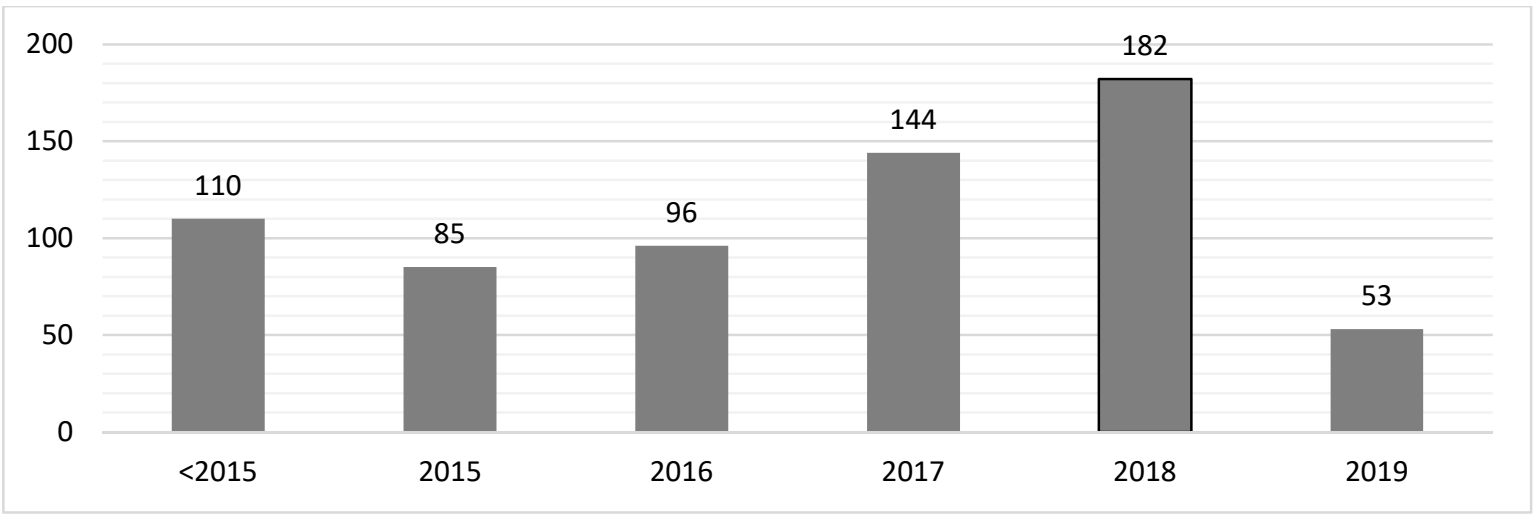

Source: Authors' work, based on Scopus systematic literature review

From 2010-2015 there were 110 citations on the papers altogether, but as the topic relevance and the number of papers forms 2015 grow, citations number sharply increase every year. In 2015, there were 85 citations, in 2016, 96 citations, after which the number of citations of the paper related to "Twitter" and "Tourism" demonstrates the exponential growth. In 2017, there were 144 citations, and in 2018 there were 182 citations. In the first two months of 2019, there were already 53 citations. An upward trend in the number of citations suggests increasing and relevance attention to the topic.

Papers related to Twitter and tourism with the highest number of citations were outlined in order to identify the most important papers and authors in the network (Table 1). The article with the highest number of citations was written by Hong and coauthors (2012), and it generated 247 citations. Sotiriadis et al. (2103) were cited 124 times. Leung et al. (2015) were cited 66 times, followed by with the paper by Sevin et al. (2013) which was cited 35 times. Park et al. (2016) were cited 22 times. As in other areas, the number of citations is higher for older papers. 
Table 1

Papers related to Twitter and tourism with the highest number of citations (10+ citations)

\begin{tabular}{|c|c|c|c|}
\hline Author (Year) & Paper title & $\begin{array}{l}\text { Publication } \\
\text { year }\end{array}$ & $\begin{array}{c}\text { \# of } \\
\text { citations }\end{array}$ \\
\hline $\begin{array}{l}\text { Hong et al., } \\
\text { (2012) }\end{array}$ & Discovering geographical topics in the Twitter stream & 2012 & 247 \\
\hline $\begin{array}{l}\text { Sotiriadis ef } \\
\text { al., (2013) }\end{array}$ & $\begin{array}{l}\text { Electronic word-of-mouth and online reviews in } \\
\text { tourism services: The use of Twitter by tourists }\end{array}$ & 2013 & 124 \\
\hline $\begin{array}{l}\text { Leung et al. } \\
\qquad(2015)\end{array}$ & $\begin{array}{l}\text { The Marketing Effectiveness of Social Media in the } \\
\text { Hotel Industry: A Comparison of Facebook and } \\
\text { Twitter }\end{array}$ & 2015 & 66 \\
\hline Sevin (2013) & $\begin{array}{l}\text { Places going viral: Twitter usage patterns in } \\
\text { destination marketing and place branding }\end{array}$ & 2013 & 35 \\
\hline $\begin{array}{l}\text { Park et al. } \\
\text { (2016) }\end{array}$ & $\begin{array}{c}\text { Using Twitter Data for Cruise Tourism Marketing and } \\
\text { Research }\end{array}$ & 2016 & 22 \\
\hline $\begin{array}{l}\text { Philander et } \\
\text { al. (2016) }\end{array}$ & $\begin{array}{l}\text { Twitter sentiment analysis: Capturing sentiment from } \\
\text { integrated resort tweets }\end{array}$ & 2016 & 21 \\
\hline $\begin{array}{l}\text { Shimada ef } \\
\text { al. (2011) }\end{array}$ & $\begin{array}{l}\text { Analyzing tourism information on Twitter for a local } \\
\text { city }\end{array}$ & 2011 & 16 \\
\hline $\begin{array}{l}\text { Claster et al. } \\
\quad(2010)\end{array}$ & $\begin{array}{c}\text { Thailand - Tourism, and conflict. Modeling sentiment } \\
\text { from Twitter tweets using naïve Bayes and } \\
\text { unsupervised artificial neural nets }\end{array}$ & 2010 & 16 \\
\hline $\begin{array}{l}\text { Tenkanen et } \\
\text { al. (2017) }\end{array}$ & $\begin{array}{l}\text { Instagram, Flickr, or Twitter: Assessing the usability of } \\
\text { social media data for visitor monitoring in protected } \\
\text { areas }\end{array}$ & 2017 & 13 \\
\hline $\begin{array}{l}\text { Williams et al. } \\
\qquad(2015)\end{array}$ & $\begin{array}{l}\text { Community crosstalk: An exploratory analysis of } \\
\text { destination and festival eWOM on Twitter }\end{array}$ & 2015 & 13 \\
\hline $\begin{array}{l}\text { Bassolas et al. } \\
\qquad(2016)\end{array}$ & Touristic site attractiveness is seen through Twitter & 2016 & 12 \\
\hline $\begin{array}{l}\text { Abbasi et al. } \\
\text { (2015) }\end{array}$ & $\begin{array}{l}\text { Utilizing location-based social media in travel survey } \\
\text { methods: Bringing Twitter data into the play }\end{array}$ & 2015 & 11 \\
\hline
\end{tabular}

Source: Authors' work, based on Scopus systematic literature review

Figure 4 presents countries of origin of authors who published papers related to Twitter and Tourism. The analysis of world geographical distribution is based on author institute address. The United States is the country which has farthermost articles on the topic (16). Other countries which published two or more papers related to tourism and Twitter include Japan with 7 papers, Spain with 5 articles, Australia and the United Kingdom with 4 documents and Belgium, Canada, Greece, Peru, Saudi Arabia, Singapore, and South Africa with two papers. We can presume that the reason the US has the highest number publications is that the US is the country with the most Twitter users globally (47,05 million in January 2019 according to Statista (2019)), and is the second country omnipresent by the number of travelers (Vu et al., 2018). 
Figure 4

Publication countries of papers related to tourism and Twitter (2+ countries)

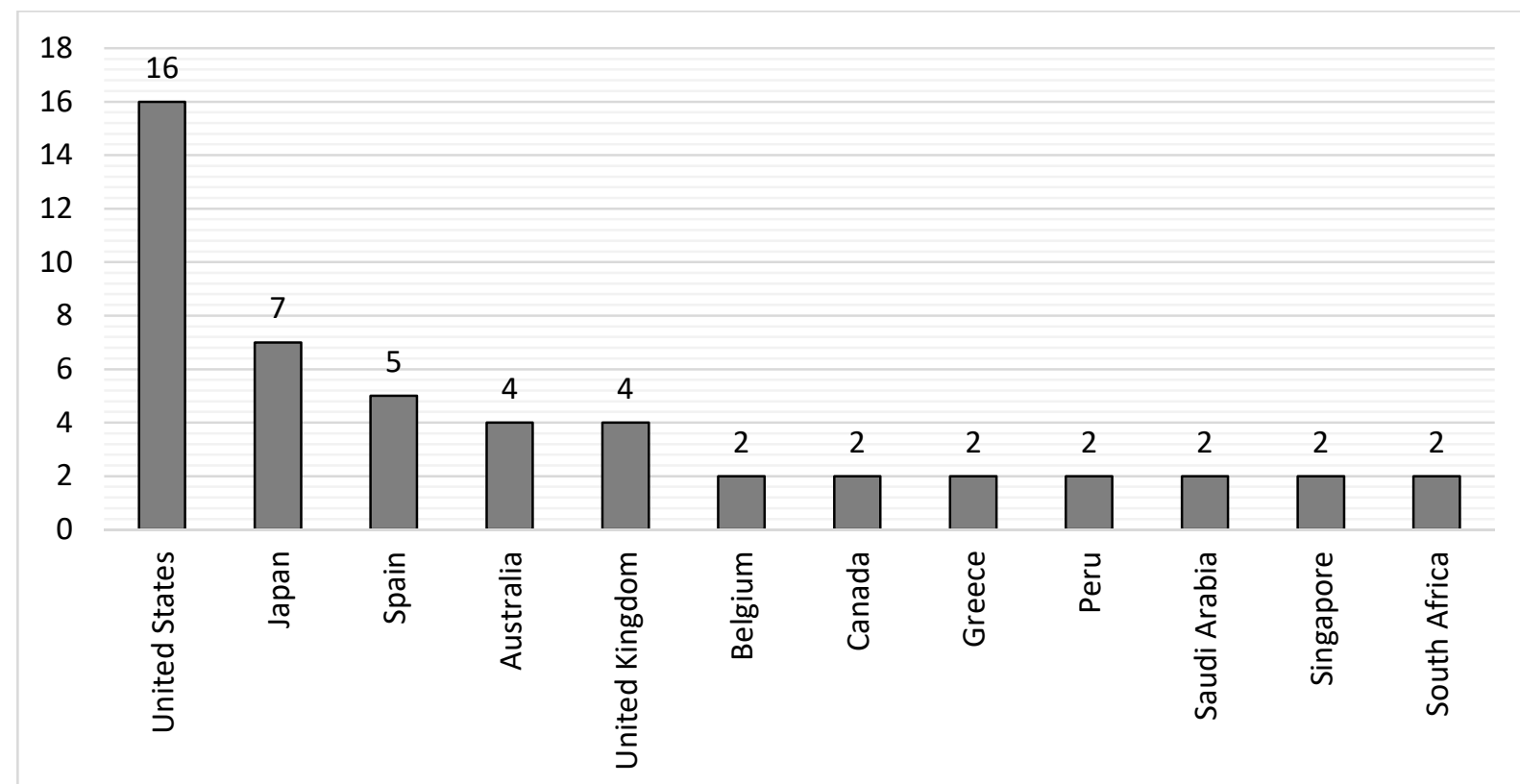

Source: Authors' work, based on Scopus systematic literature review

\section{Text mining analysis}

Text mining of the papers related to Twitter and tourism was conducted in order to identify emerging research trends, with the goal to provide insights into the development of this research field (Jiang et al., 2016). Text mining of paper abstracts was conducted.

Table 2 presents the most frequent words that occur in papers related to tourism and Twitter. The Column Term Frequency-Inverse Document Frequency (TF*IDF) of Table 2 contains values of metrics for an estimation of the importance of a word in a collection of papers. In Table 3, the same metrics were presented for phrases. The importance is based on the ratio between the frequency at which a phrase occurs in a document and the total number of words in the document (TF), along with the logarithm of the ratio between the total number of documents the phrase occurs in and the total number of documents present in the collection (*IDF) (Pejić Bach et al., 2019). Within the context of this research, TD*IDF refers to documents consisting of term Twitter related to the tourism sector. The TF-IDF metric is used to pre-process the collection of documents to exclude words that cannot be considered as keywords (Montaner et al., 2003).

Extracted words identify the most critical themes regarded to the topic. Beside general words which are connected to the subject area such as "Twitter", "social", "media", "data", "tourism", "tourists", "hotels", "places" and "location", words connected to the specific knowledge, trends and interests were distinguished as well. Words like "analysis," "marketing," "model," "communication" point out the relationship between "Twitter and tourism" and business strategies and discovering new knowledge. 
Table 2

The most frequent words occurring in abstracts of extracted papers (+10 frequency)

\begin{tabular}{|c|c|c|c|c|c|c|c|}
\hline & FREQUENCY & $\begin{array}{l}\text { \% } \\
\text { SHOWN }\end{array}$ & $\begin{array}{l}\% \\
\text { PROCESSED }\end{array}$ & $\begin{array}{l}\% \\
\text { TOTAL }\end{array}$ & $\begin{array}{l}\text { NO. } \\
\text { CASES }\end{array}$ & $\begin{array}{l}\% \\
\text { CASES }\end{array}$ & $\begin{array}{l}\text { TF • } \\
\text { IDF }\end{array}$ \\
\hline TWITTER & 90 & $10.25 \%$ & $2.71 \%$ & $1.35 \%$ & 37 & $78.72 \%$ & 9.4 \\
\hline SOCIAL & 54 & $6.15 \%$ & $1.63 \%$ & $0.81 \%$ & 29 & $61.70 \%$ & 11.3 \\
\hline MEDIA & 49 & $5.58 \%$ & $1.48 \%$ & $0.73 \%$ & 26 & $55.32 \%$ & 12.6 \\
\hline DATA & 43 & $4.90 \%$ & $1.29 \%$ & $0.64 \%$ & 17 & $36.17 \%$ & 19 \\
\hline INFORMATION & 35 & $3.99 \%$ & $1.05 \%$ & $0.52 \%$ & 17 & $36.17 \%$ & 15.5 \\
\hline TOURISM & 35 & $3.99 \%$ & $1.05 \%$ & $0.52 \%$ & 14 & $29.79 \%$ & 18.4 \\
\hline HOTEL & 32 & $3.64 \%$ & $0.96 \%$ & $0.48 \%$ & 7 & $14.89 \%$ & 26.5 \\
\hline TWEETS & 32 & $3.64 \%$ & $0.96 \%$ & $0.48 \%$ & 20 & $42.55 \%$ & 11.9 \\
\hline ANALYSIS & 30 & $3.42 \%$ & $0.90 \%$ & $0.45 \%$ & 20 & $42.55 \%$ & 11.1 \\
\hline MARKETING & 26 & $2.96 \%$ & $0.78 \%$ & $0.39 \%$ & 12 & $25.53 \%$ & 15.4 \\
\hline DESTINATION & 25 & $2.85 \%$ & $0.75 \%$ & $0.37 \%$ & 14 & $29.79 \%$ & 13.1 \\
\hline TRAVEL & 25 & $2.85 \%$ & $0.75 \%$ & $0.37 \%$ & 8 & $17.02 \%$ & 19.2 \\
\hline NETWORK & 21 & $2.39 \%$ & $0.63 \%$ & $0.31 \%$ & 10 & $21.28 \%$ & 14.1 \\
\hline PLACES & 20 & $2.28 \%$ & $0.60 \%$ & $0.30 \%$ & 7 & $14.89 \%$ & 16.5 \\
\hline MODEL & 19 & $2.16 \%$ & $0.57 \%$ & $0.28 \%$ & 8 & $17.02 \%$ & 14.6 \\
\hline INTEREST & 17 & $1.94 \%$ & $0.51 \%$ & $0.25 \%$ & 9 & $19.15 \%$ & 12.2 \\
\hline COMMUNICATION & 16 & $1.82 \%$ & $0.48 \%$ & $0.24 \%$ & 8 & $17.02 \%$ & 12.3 \\
\hline TOURIST & 16 & $1.82 \%$ & $0.48 \%$ & $0.24 \%$ & 8 & $17.02 \%$ & 12.3 \\
\hline USERS & 16 & $1.82 \%$ & $0.48 \%$ & $0.24 \%$ & 11 & $23.40 \%$ & 10.1 \\
\hline ONLINE & 15 & $1.71 \%$ & $0.45 \%$ & $0.22 \%$ & 12 & $25.53 \%$ & 8.9 \\
\hline TOURISTS & 15 & $1.71 \%$ & $0.45 \%$ & $0.22 \%$ & 8 & $17.02 \%$ & 11.5 \\
\hline MESSAGES & 13 & $1.48 \%$ & $0.39 \%$ & $0.19 \%$ & 8 & $17.02 \%$ & 10 \\
\hline USER & 13 & $1.48 \%$ & $0.39 \%$ & $0.19 \%$ & 9 & $19.15 \%$ & 9.3 \\
\hline ATTITUDES & 11 & $1.25 \%$ & $0.33 \%$ & $0.16 \%$ & 3 & $6.38 \%$ & 13.1 \\
\hline PLACE & 11 & $1.25 \%$ & $0.33 \%$ & $0.16 \%$ & 6 & $12.77 \%$ & 9.8 \\
\hline LOCATION & 10 & $1.14 \%$ & $0.30 \%$ & $0.15 \%$ & 5 & $10.64 \%$ & 9.7 \\
\hline PEOPLE & 10 & $1.14 \%$ & $0.30 \%$ & $0.15 \%$ & 7 & $14.89 \%$ & 8.3 \\
\hline SITES & 10 & $1.14 \%$ & $0.30 \%$ & $0.15 \%$ & 4 & $8.51 \%$ & 10.7 \\
\hline
\end{tabular}

Source: Authors' work, based on Scopus systematic literature review

Phrases were extracted with the lowest frequency of three phrases and the maximum of five words. Phrases were divided into general phrases related to the issue ("social media", "social network", "Twitter data", "hotel industry"), and phrases which indicate the relevance of the subject in terms of business strategy, planning and tourist decision making ("marketing effectiveness", "attitude toward hotel", destination marketing projects", mobility patterns", "network analysis"). 
Table 3

Most frequent phrases occurring in the abstracts of extracted papers ( +3 frequency)

\begin{tabular}{|c|c|c|c|c|c|}
\hline & FREQUENCY & NO. CASES & $\%$ CASES & LENGTH & TF ・ IDF \\
\hline SOCIAL MEDIA & 43 & 23 & $48.94 \%$ & 2 & 13.3 \\
\hline DESTINATION MARKETING & 8 & 4 & $8.51 \%$ & 2 & 8.6 \\
\hline TWITTER DATA & 8 & 4 & $8.51 \%$ & 2 & 8.6 \\
\hline MARKETING EFFECTIVENESS & 7 & 2 & $4.26 \%$ & 2 & 9.6 \\
\hline ATTITUDES TOWARD HOTEL & 6 & 2 & $4.26 \%$ & 3 & 8.2 \\
\hline ELECTRONIC WORD OF MOUTH & 6 & 4 & $8.51 \%$ & 4 & 6.4 \\
\hline SOCIAL MEDIA DATA & 6 & 3 & $6.38 \%$ & 3 & 7.2 \\
\hline DESTINATION MARKETING PROJECTS & 5 & 2 & $4.26 \%$ & 3 & 6.9 \\
\hline SOCIAL NETWORK & 5 & 4 & $8.51 \%$ & 2 & 5.4 \\
\hline CRISIS COMMUNICATION & 4 & 1 & $2.13 \%$ & 2 & 6.7 \\
\hline FLICKR PHOTOS & 4 & 2 & $4.26 \%$ & 2 & 5.5 \\
\hline HOTEL INDUSTRY & 4 & 2 & $4.26 \%$ & 2 & 5.5 \\
\hline HOTEL OCCUPANCY & 4 & 1 & $2.13 \%$ & 2 & 6.7 \\
\hline NETWORK ANALYSIS & 4 & 4 & $8.51 \%$ & 2 & 4.3 \\
\hline PLACE DATABASES & 4 & 2 & $4.26 \%$ & 2 & 5.5 \\
\hline PLACES OF INTEREST & 4 & 2 & $4.26 \%$ & 3 & 5.5 \\
\hline TOURISM FLOWS & 4 & 1 & $2.13 \%$ & 2 & 6.7 \\
\hline TOURIST DESTINATIONS & 4 & 4 & $8.51 \%$ & 2 & 4.3 \\
\hline ANALYSIS OF TWEETS & 3 & 3 & $6.38 \%$ & 3 & 3.6 \\
\hline HUMAN MOBILITY & 3 & 3 & $6.38 \%$ & 2 & 3.6 \\
\hline MOBILITY PATTERNS & 3 & 1 & $2.13 \%$ & 2 & 5 \\
\hline ONLINE SOCIAL & 3 & 3 & $6.38 \%$ & 2 & 3.6 \\
\hline POSITIVE ATTITUDES & 3 & 2 & $4.26 \%$ & 2 & 4.1 \\
\hline SOCIAL MEDIA SITES & 3 & 2 & $4.26 \%$ & 3 & 4.1 \\
\hline SOCIAL NETWORKING & 3 & 3 & $6.38 \%$ & 2 & 3.6 \\
\hline TERRORIST ATTACK & 3 & 1 & $2.13 \%$ & 2 & 5 \\
\hline TOURISM PURPOSES & 3 & 1 & $2.13 \%$ & 2 & 5 \\
\hline TOURIST BEHAVIOR & 3 & 1 & $2.13 \%$ & 2 & 5 \\
\hline TOURISTIC SITES & 3 & 1 & $2.13 \%$ & 2 & 5 \\
\hline TRAVEL RISK & 3 & 1 & $2.13 \%$ & 2 & 5 \\
\hline TRAVEL WRITING & 3 & 1 & $2.13 \%$ & 2 & 5 \\
\hline TWITTER ACCOUNTS & 3 & 2 & $4.26 \%$ & 2 & 4.1 \\
\hline TWITTER AND FLICKR & 3 & 2 & $4.26 \%$ & 3 & 4.1 \\
\hline TWITTER USER & 3 & 2 & $4.26 \%$ & 2 & 4.1 \\
\hline
\end{tabular}

Source: Authors' work

To distinct the association between most frequent phrases of extracted papers, we used the Jaccard's coefficient similarity measure, and develop cluster analysis of phrases (Figure 5). The two most common phrases were social media and destination marketing, which connect Twitter as a social media network with marketing strategies on various levels. Marketing analysis and effectiveness appear continuously together, which lead us to assert that developing destination marketing strategies with Twitter utilization is the topic of relevance and one the key trend for the given topic.

The cluster analysis distinguishes seven topics based on phrases of extracted papers related to Twitter and tourism (Figure 5.)

- Cluster 1 include the following phrases: "analysis of tweets", "online social", "human mobility", "touristic sites", "network analysis", "tourism flows", and "Twitter data". The first Cluster consists of papers whom all use Twitter geo located analytics data in order to find patterns, topics and relations which provide a base to create a tourism marketing strategy for hotel or country. The given papers conduct comprehensive and depth analysis to examine tweets based 
on geographical location, topic or interest and, thereupon reveal preferences of the travelers. Results of social media analytics can provide essence for creating long term business strategies, developing comparative advantage and market spreading. For example, article " The mobility network of European tourists: a longitudinal study and a comparison with geo-located Twitter data" point out the trends for EU travelers as to shift to homogenous traveling preferences and shorter distance traveling. "Vacation Finder: A tool for collecting, analyzing, and visualizing geotagged Twitter data to find top vacation spots" paper provides software which can produce a personalized vacation plan. "Using Twitter Data for Cruise Tourism Marketing and Research " article analyze trends and preferences for cruise tourism, "Tourist site attractiveness is seen through Twitter" unveil relations between touristic sites and find which ones are more tightly interconnected, and "Discovering Geographical topic in the Twitter stream" emphasize how to model human mobility. All papers in Cluster 1 stress out the importance of understanding and tracking travelers' preferences and plans, and developing effective business strategies and increase profit.

- Cluster 2 includes "social media data" and "Twitter and Flickr" phrases. Suggested Cluster consists of papers, which analyze data collection via Twitter in situations where visitor information is hard to collect. For instance, in protected areas or when special mega events take place. That kind of information is valuable from infrastructure aspects, where creating a possibility of developing high-end VR technologies such as cyberspaces. Additionally, in cluster 2 Twitter posts performance is compared to other social networks (Facebook, Instagram, Flickr), so the recommendations further development can be extracted. Examples of papers in the Cluster 2 are: "Digital image of the city during and after a mega-event: Poznan, Euro 2012 and Twitter users" "Instagram, Flickr, or Twitter: Assessing the usability of social media data for visitor monitoring in protected areas."

- Cluster 3 include following phrases: "attitudes toward hotel", "marketing effectiveness", "electronic word of mouth", "positive attitudes", "hotel industry", "social media sites", "destination marketing projects" and "Twitter accounts". The documents in Cluster 3 focuses on the relationship between patterns of microblogging on Twitter and hotel and destination marketing effectiveness. They explore the impact that Tweets have on audience attitude on hotel or place branding, booking intentions and electronic word of mouth. All papers established a positive correlation between Twitter and social media posts and marketing effectiveness. Taken that information into consideration, hotels, and places can now extend their marketing schemes and pay more attention to utilize their Twitter account to widen their broadcast message and reach target audiences as increase the number of booking and improve their brand. It is confirmed that all social networks generate the same effect and need the same marketing strategy. Papers included in Cluster 3 are: "Marketing effectiveness of hotel Twitter accounts: the case of Saudi Arabia," "The Marketing Effectiveness of Social Media in the Hotel Industry: A Comparison of Facebook and Twitter," "Places going viral: Twitter usage patterns in destination marketing and place branding."

- Cluster 4 include four phrases: "Flickr photos", "place databases", "places of interest" and "social media". Phrases included in Cluster 4 are related to the usage of Twitter and other social media to discover new places. Geographically annotated information gathered from social media can be 
used to discover points that are not yet obtained online. That could be useful for tourism development. Moreover, errors in Foursquare and Google could be corrected. An example is a paper "Discovering characterizing places of interest using Flickr and Twitter" which integrates two social networks to discover new potentially interesting tourist places.

- Cluster 5 include phrases "destination marketing", "hotel occupancy", "tourist destinations". The following Cluster identifies documents which use prominent analytic methods such as longitudinal case study, text mining, and artificial neural networks in order to forecast hotel occupancies based on Twitter data. They extract tweets and retweets related to events and happening nearby the hotel area and on that base predict hotel occupancy. Stated could be of immense importance for the whole hospitality industry, in terms of a base for developing strategies, infrastructural preparations and cost reductions. Possible further investigations could define the other factors of hotel occupancy, and It would be interesting to see what else affect hotel occupancy and therefore extenuate forecasting and predicting in the tourism and hospitality industry. Example of an article included in the Cluster is: "Harnessing stakeholder input on Twitter: A case study of short breaks in Spanish tourist cities."

- Cluster 6 identify "crisis communication" and "terrorist attack." Phrases in Cluster 6 point present the insights of Twitter usage during a crisis's situation. Example of paper $s$ in cluster 6 are: "Destinations' response to terrorism on Twitter." Findings are that Twitter is not effective enough in terms of how to stay safe during a terrorist attack or crises, the only tweets in 7 attacks in 6 EU cities from destinations or hotels were in the role of victims not one piece of information on how to stay safe. This identifies a need to change such a strategy in order to save lives and better communication strategies in crisis situations - Paper Destinations' response to terrorism on Twitter.

Figure 5

Cluster analysis of phrases of extracted papers ( +3 frequency)
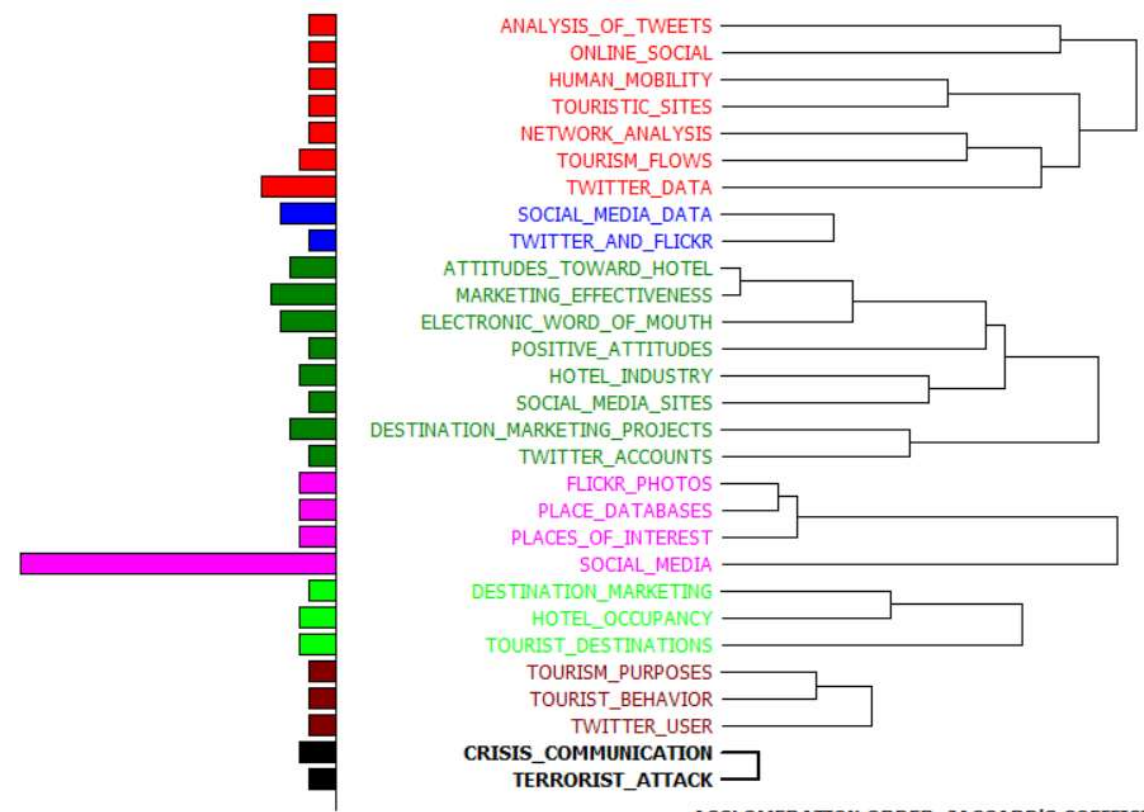

3 SINGLE WORD CLUSTERS REMOVED

AGGLOMERATION ORDER: JACCARD'S COEFFICIENT (OCCURRENCE)

Source: Authors' work, based on Scopus systematic literature review, using Wordstat 


\section{Conclusion}

The goal of this paper was to identify the relevance of the usage of Twitter in tourism and discover patterns, trends, and methods in order to achieve both academic and practice contribution.

By reviewing 46 relevant papers and conducting systematic literature review and text mining, new knowledge has been revealed. Firstly, systematic literature review established the relevance of the given topic by the perpetual growth of the number of papers over the last few years and the substantial increase of the citation during a time. Secondly, systematic literature review confirms interdisciplinary interest on the topic, since papers were classified into various topics, although business and management were the most prevalent. so as the overall relevance to the business since the various areas of research was found included by analyzing the papers. The fact that the most cited papers emphasize the questions such as modeling the human mobility, tourist decision making, and need for a conceptual framework of the area stress out the fundamental issues for the further researches.

Text mining extracted the words phrases and themes that most often occur in papers related to tourism and Twitter. The most common words and phrases distinguished several of patterns interests related to the theme. Extracted words and phrases were divided into two groups: general and specific. Specific words and phrases unveiled the relationship between the given topic and business strategies and planning. The cluster analysis singled out the trends, methods, and gaps in the literature. It specified six topics where an assorted number of sources confirmed the relationship of Twitter posts and tourist's decision making, hotel branding, e-WoM, and booking intentions so the hotels and touristic destinations can create business and marketing strategies and more distinguished and personalized supply. Personalized supply is singled out as a critical factor in gaining competitive advantage and marketing spread.

Utilization Twitter posts for business planning and adoption sophisticated tools as longitudinal studies, text mining, and methods as artificial neural networks require further investigations as well as developing new tactics both for destinations and travel intermediaries. Furthermore, the usage of Twitter in tourism as a support for implementing high-end technologies, such as virtual reality is demonstrated; as well as the usage of Twitter for finding new potentially interesting tourist places, but also threats such as terrorism and attacks.

Additionally, gaps in the research and practice were identified. Twitter was established as the first stop for people to search for information for, but concurrently, the effectiveness of Twitter showed low in times of crisis and terrorist attack. Therefore, the authors should focus on the search for a solution in order to address this vital issue and increase safety. Finally, the future studies are suggested in order to establish the factors which impact the hotel occupancy based on Tweets on the close area of the hotels or the destination.

This study was exploratory and interpretative in nature, and it thoroughly demonstrates the strategic importance of Twitter for tourism competitiveness, which implicates exciting topics for further investigations. Knowledge from this paper could serve as a support for strategic planning, market spreading and modeling new theoretical frameworks. 


\section{References}

1. Abbasi, A., Rashidi, T. H., Maghrebi, M., Waller, S. T. (2015), "Utilising location based social media in travel survey methods: bringing Twitter data into the play", in Proceedings of the 8th ACM SIGSPATIAL International Workshop on Location-Based Social Networks, Bellevue, WA, USA, ACM.

2. Amaro, S., Duarte, P., Henriquez, C. (2016), "Travelers' use of social media: A clustering approach", Annals of Tourism Research, Vol. 59, pp. 1-15.

3. Antoniadis, K., Zafiropoulos, K., Varna, V. (2015), "Communities of followers in tourism Twitter accounts of European countries", European Journal of Tourism, Hospitality and Recreation, Vol. 6, No. 1, pp. 11-26.

4. Bassolas, A., Lenormand, M., Tugores, A., Gonçalves, B., Ramasco, J. J. (2016), "Touristic site attractiveness seen through Twitter", EPJ Data Science, Vol. 5, No.1.

5. Baym, N. K. (2015), Personal connections in the digital age, John Wiley \& Sons.

6. Bruhn, M., Schoenmueller, V., Schäfer, D. B. (2012), "Are social media replacing traditional media in terms of brand equity creation?", Management Research Review, Vol. 35, No. 9, pp. 770-790.

7. Claster, W. B., Cooper, M., Sallis, P. (2010), "Thailand--Tourism and conflict: Modeling sentiment from Twitter tweets using naïve Bayes and unsupervised artificial neural nets", in 2nd International Conference on Computational Intelligence, Modelling and Simulation, Tuban, Indonesia, IEEE, pp. 89-94.

8. Deddens, L. (2011), "Social media in science", eco. Mont-Journal on Protected Mountain Areas Research, Vol. 3, No. 2, pp. 49-52.

9. eMarketer (2013), "In Asia-Pacific, social media inspires travellers", available at: http://www.emarketer.com/Article/Asia-Pacific-Social-Media-Inspires-Travelers/1009605 (04 April 2018)

10. Everitt, B. S., Landau, S., Leese, M., Stahl, D. (2011), "Hierarchical clustering", Cluster analysis, Vol. 5, pp. 71-110.

11. Gasparyan, A. Y., Ayvazyan, L., Blackmore, H., Kitas, G. D. (2011), "Writing a narrative biomedical review: considerations for authors, peer reviewers, and editors", Rheumatology International, Vol. 31, No. 11, pp. 1409.

12. Gonçalves, B., Perra, N., Vespignani, A. (2011), "Modeling users' activity on Twitter networks: Validation of Dunbar's number", PLOS ONE, Vol. 6, No. 8.

13. Gupta, V., Lehal, G. S. (2009), "A survey of text mining techniques and applications", Journal of emerging technologies in web intelligence, Vol. 1, No.1, pp. 60-76.

14. Gutiérrez, J., García-Palomares, J. C., Romanillos, G., Salas-Olmedo, M. H. (2017), "The eruption of Airbnb in tourist cities: Comparing spatial patterns of hotels and peer-to- peer accommodation in Barcelona", Tourism Management, Vol. 62, pp. 278-291.

15. Hong, L., Ahmed, A., Gurumurthy, S., Smola, A. J., \& Tsioutsiouliklis, K. (2012), "Discovering geographical topics in the Twitter stream", in Proceedings of the 21 st international conference on World Wide Web, Lyon, France, ACM, pp. 769-778.

16. Jiang, H., Qiang, M., Lin, P. (2016), "A topic modeling based bibliometric exploration of hydropower research", Renewable Sustainable Energy Reviews, Vol. 57, pp. 226-237.

17. Kim, J., Ahn, K., Chung, N. (2013), "Examining the factors affecting perceived enjoyment and usage intention of ubiquitous tour information services: A service quality perspective", Asia Pacific Journal of Tourism Research, Vol. 18, No. 6, pp. 598-617.

18. Kirilenko, A. P., Stepchenkova, S. O. (2014), "Public microblogging on climate change: One year of Twitter worldwide", Global environmental change, Vol. 26, pp. 171-182.

19. Kwak, H., Lee, C., Park, H., Moon, S. (2010), "What is Twitter, a social network or a news media", in Proceedings of the 19th International conference on World Wide Web, Raleigh, North Carolina, USA, ACM, pp. 591-600.

20. Law, R., Chan, I. C. C., Wang, L. (2018), "A comprehensive review of mobile technology use in hospitality and tourism", Journal of Hospitality Marketing \& Management, Vol. 27, No. 6, pp. 626-648.

21. Leung, D., Law, R., Van Hoof, H., Buhalis, D. (2013), "Social media in Tourism and Hospitality: A Literature Review", Journal of Travel \& Tourism Marketing, Vol. 30, No. 1-2, pp. 3-22. 
22. Leung, X. Y., Bai, B., Stahura, K. A. (2015), "The marketing effectiveness of social media in the hotel industry: A comparison of Facebook and Twitter", Journal of Hospitality \& Tourism Research, Vol. 39, No. 2, pp. 147-169.

23. Moher, D., Stewart, L., Shekelle, P. (2016), "Implementing PRISMA-P: recommendations for prospective authors", Systematic reviews, Vol. 5, No. 15.

24. Montaner, M., López, B., De La Rosa, J. L. (2003), "A taxonomy of recommender agents on the internet", Artificial intelligence review, Vol. 19, No. 4, pp. 285-330.

25. Munar, A. M., Jacobsen, J. K. S. (2013), "Trust and involvement in tourism social media and web-based travel information sources", Scandinavian Journal of Hospitality and Tourism, Vol. 13, No. 1, pp. 1-19.

26. Park, S. B., Ok, C. M., Chae, B. K. (2016), "Using Twitter data for cruise tourism marketing and research", Journal of Travel \& Tourism Marketing, Vol. 33, No. 6, pp. 885-898.

27. Pejić Bach, M., Krstić, Ž., Seljan, S., Turulja, L. (2019), "Text Mining for Big Data Analysis in Financial Sector: A Literature Review", Sustainability, Vol. 11, No. 5, pp. 1277.

28. Philander, K., Zhong, Y. (2016), "Twitter sentiment analysis: capturing sentiment from integrated resort tweets", International Journal of Hospitality Management, Vol. 55, pp. 1624.

29. Sevin, H. E. (2013), "Places going viral: Twitter usage patterns in destination marketing and place branding", Journal of Place Management and development, Vol. 6, No. 3, pp. 227239.

30. Shimada, K., Inove, S., Maeda, H., Endo, T. (2011), "Analyzing tourism information on Twitter for a local city.", in First ACIS International Symposium on Software and Network Engineering, Seoul, South Korea, IEEE, pp. 61-66.

31. Sotiriadis, M. D., Van Zyl, C. (2013), "Electronic word-of-mouth and online reviews in tourism services: the use of Twitter by tourists", Electronic Commerce Research, Vol. 13, No. 1, pp. 103-124.

32. Statista (2018), "Number of social media users worldwide from 2010 to 2021 (in billions)", available at: https://www.statista.com/statistics/278414/number-of-worldwide-socialnetwork-users/ (07 May 2018)

33. Statista (2019), "Leading countries based on number of Twitter users as of January 2019 (in millions)", available at: https://www.statista.com/statistics/242606/number-of-activeTwitter-users-in-selected-countries/ (23 February 2019)

34. Tenkanen, H., Di Minin, E., Heikinheimo, V., Hausmann, A., Herbst, M., Kajala, L., Toivonen, T. (2017), "Instagram, Flickr, or Twitter: Assessing the usability of social media data for visitor monitoring in protected areas", Scientific reports, Vol. 7, No. 1.

35. Tripadvisor (2014), "TripBarometer April 2014: Global edition", available at: http://www.tripadvisor.com/TripAdvisorlnsights/n2200/tripbarometer-april-2014-globaledition/ (04 April 2018)

36. Trusov, M., Bucklin, R. E., Pauwels, K. (2009), "Effects of word-of-mouth versus traditional marketing: findings from an internet social networking site", Journal of marketing, Vol. 73, No. 5, pp. 90-102.

37. Tung, V. W. S., Ritchie, J. B. (2011), "Exploring the essence of memorable tourism experiences", Annals of tourism research, Vol. 38, No. 4, pp. 1367-1386.

38. Uşaklı, A., Koç, B., Sönmez, S. (2017), "How social 'are destinations? Examining European DMO social media usage", Journal of destination marketing \& management, Vol. 6, No. 2 , pp. 136-149.

39. Vu, H. Q., Li, G., Law, R. (2018), "Cross-Country Analysis of Tourist Activities Based on VenueReferenced Social Media Data", Journal of Travel Research, Vol. 46, No. 3, pp. 245-255.

40. Wells, W. H. (2011), "Social media and social networking: What's the difference?", available at: http://www.williamhwells.com/201 1/06/18/social-media-and-social- networking-whatsthe-difference/ (04 April 2018)

41. Wiggerts, T. A. (1997), "Using clustering algorithms in legacy systems remodularization", in Proceedings of the Fourth Working Conference on Reverse Engineering, Amsterdam, Netherlands, IEEE, pp. 33-43.

42. World Travel Market (2013), World Travel Market 2013 industry report, London. 
43. Xiang, Z., Schwartz, Z., Gerdes Jr, J. H., Uysal, M. (2015), "What can big data and text analytics tell us about hotel guest experience and satisfaction?", International Journal of Hospitality Management, Vol. 44, pp. 120-130.

44. Zeng, B., Gerritsen, R. (2014), "What do we know about social media in tourism? A review", Tourism Management Perspectives, Vol. 10, pp. 27-36.

\section{Appendix List of papers included in the analysis}

1. Abbasi, A., Rashidi, T. H., Maghrebi, M., Waller, S. T. (2015), "Utilising location based social media in travel survey methods: bringing Twitter data into the play", in Proceedings of the 8th ACM SIGSPATIAL International Workshop on Location-Based Social Networks, Bellevue, WA, USA, ACM.

2. Abeza, G., Pegoraro, A., Naraine, M. L., Séguin, B., O'Reilly, N. (2014), "Activating a global sport sponsorship with social media: an analysis of TOP sponsors, Twitter, and the 2014 Olympic Games", International Journal of Sport Management and Marketing, Vol. 15, No. 3-4, pp. 184-213.

3. Alansari, M. T., Velikova, N., Jai, T. M. (2018), "Marketing effectiveness of hotel Twitter accounts: the case of Saudi Arabia", Journal of Hospitality and Tourism Technology, Vol. 9, No. 1, pp. 65-79.

4. Alowibdi, J. S., Ghani, S., Mokbel, M. F. (2014), "VacationFinder: A tool for collecting, analyzing, and visualizing geotagged Twitter data to find top vacation spots", in Proceedings of the 7th ACM SIGSPATIAL International Workshop on Location-Based Social Networks, Dallas/Fort Worth, Texas, USA, ACM, pp. 9-12.

5. Atkinson, D. (2013), "The new travel journalism - From Theroux to Twitter", in Proceedings of the 5th International Conference on Internet Technologies and Applications, pp. 392-393.

6. Azariah, D. (2012), "Beyond the blog: The networked self of travel bloggers on Twitter", Journal of Media and Communication, Vol.1, No. 4, pp. 63-78.

7. Barbe, D., Pennington-Gray, L., Schroeder, A. (2018), "Destinations' response to terrorism on Twitter", International Journal of Tourism Cities, Vol. 4, No. 4, pp. 495-512.

8. Bassolas, A., Lenormand, M., Tugores, A., Gonçalves, B., Ramasco, J. J. (2016), "Touristic site attractiveness seen through Twitter", EPJ Data Science, Vol. 5, No.1, pp. 12.

9. Bigné, E., Oltra, E., Andreu, L. (2019), "Harnessing stakeholder input on Twitter: A case study of short breaks in Spanish tourist cities", Tourism Management, Vol. 71, pp. 490-503.

10. Bokunewicz, J. F., Shulman, J. (2017), "Influencer identification in Twitter networks of destination marketing organizations", Journal of Hospitality and Tourism Technology, Vol. 8, No. 2, pp. 205-219.

11. Bonsón, E., Bednárová, M., Wei, S. (2016), "Corporate Twitter use and stakeholder engagement: An empirical analysis of the Spanish hotel industry", European Journal of Tourism Research, Vol. 13, pp. 69-83.

12. Cajachahua, L., Burga, I. (2017), "Sentiments and opinions from Twitter about Peruvian touristic places using correspondence analysis", in CEUR Workshop Proc. 2029, pp. 178-189.

13. Claster, W. B., Cooper, M., Sallis, P. (2010), "Thailand--Tourism and conflict: Modeling sentiment from Twitter tweets using naïve Bayes and unsupervised artificial neural nets", in 2010 Second International Conference on Computational Intelligence, Modelling and Simulation, Tuban, Indonesia, IEEE, pp. 89-94.

14. Garay, L., Morales Pérez, S. (2017), "Understanding the creation of destination images through a festival's Twitter conversation", International Journal of Event and Festival Management, Vol. 8, No.1, pp. 39-54.

15. Gou, Z., Tsugawa, S., Korkaew, A., Yamaguchi, S., Khamket, T., Manaskasemsak, B., Rungsawang, A. (2016), "An interest-based tour planning tool by process mining from Twitter", in Proceedings of 5th Global Conference on Consumer Electronics, Kyoto, Japan, IEEE, pp. 1-4.

16. Hermanto, D. T., Ziaurrahman, M., Bianto, M. A., Setyanto, A. (2018), "Twitter Social Media Sentiment Analysis in Tourist Destinations Using Algorithms Naive Bayes Classifier", Journal of Physics: Conference Series, Vol. 1140, No. 1. 
17. Hong, L., Ahmed, A., Gurumurthy, S., Smola, A. J., Tsioutsiouliklis, K. (2012), "Discovering geographical topics in the Twitter stream", in Proceedings of the 21 st international conference on World Wide Web, Lyon, France, ACM, pp. 769-778.

18. Ichimura, T., Kamada, S. (2012), "A generation method of filtering rules of Twitter via smartphone based participatory sensing system for tourist by interactive GHSOM and C4. 5", in Proceedings of International Conference on Systems, Man, and Cybernetics (SMC), Seoul, South Korea, IEEE, pp. 110-115.

19. Kim, W. H., Chae, B. (2018), "Understanding the relationship among resources, social media use and hotel performance: The case of Twitter use by hotels", International Journal of Contemporary Hospitality Management, Vol. 30, No. 9, pp. 2888-2907.

20. Kirilenko, A. P., Stepchenkova, S. O. (2017), "Sochi 2014 Olympics on Twitter: Perspectives of hosts and guests", Tourism Management, Vol. 63, pp. 54-65.

21. Leung, X. Y., Bai, B., Stahura, K. A. (2015), "The marketing effectiveness of social media in the hotel industry: A comparison of Facebook and Twitter", Journal of Hospitality \& Tourism Research, Vol. 39, No. 2, pp. 147-169.

22. Linares, R., Herrera, J., Cuadros, A., Alfaro, L. (2015), "Prediction of tourist traffic to Peru by using sentiment analysis in Twitter social network", in Proceedings of Latin American Computing Conference, Arequipa, Peru, IEEE, pp. 1-7.

23. Mena-Maldonado, E., Maritzol Tenemaza, R. S. (2016), "Study of the viability of using Twitter sentiment analysis in the hotel industry", in Proceedings of International Conference on ICT, society, and human beings, Madeira, Portugal, IADIS, pp. 13-19.

24. Naraine, M. L., Parent, M. M. (2017), "The evolution of Twitter communication by Youth Olympic Games organising committees", International Journal of Sport Management and Marketing, Vol. 17, No. 4-6, pp. 403-425.

25. Noyen, K., \& Wortmann, F. (2014), "Using Twitter as a Source for Travel Warnings: Understanding the Role of Information Source and Target Audience", in Kundisch, D., Suhl, L., Beckmann, L. (Eds.), MKWI 2014 - Multikonferenz Wirtschaftsinformatik, Universität Paderborn, pp. 1694-1706.

26. Nozawa, Y., Endo, M., Ehara, Y., Hirota, M., Yokoyama, S., Ishikawa, H. (2016), "Inferring tourist behavior and purposes of a Twitter user", in Pacific Rim International Conference on Artificial Intelligence, Phuket, Thailand, Springer, pp. 101-112.

27. Padilla, J. J., Kavak, H., Lynch, C. J., Gore, R. J., Diallo, S. Y. (2018), "Temporal and spatiotemporal investigation of tourist attraction visit sentiment on Twitter", PloS one, Vol. 13, No. 6.

28. Park, S. B., Kim, H. J., Ok, C. M. (2018), "Linking emotion and place on Twitter at Disneyland", Journal of Travel \& Tourism Marketing, Vol. 35, No. 5, pp. 664-677.

29. Park, S. B., Ok, C. M., Chae, B. K. (2016), "Using Twitter data for cruise tourism marketing and research", Journal of Travel \& Tourism Marketing, Vol. 33, No. 6, pp. 885-898.

30. Philander, K., Zhong, Y. (2016), "Twitter sentiment analysis: capturing sentiment from integrated resort tweets", International Journal of Hospitality Management, Vol. 55, pp. 1624.

31. Pozi, M. S. M., Wang, Y., Siriaraya, P., Kawai, Y., Jatowt, A. (2018), "Predicting Next Visited Country of Twitter Users", in Asia Information Retrieval Symposium, Springer, pp. 203-209.

32. Provenzano, D., Hawelka, B., Baggio, R. (2018), "The mobility network of European tourists: a longitudinal study and a comparison with geo-located Twitter data", Tourism Review, Vol. 73, No.1, Vol. 28-43.

33. Raamkumar, A. S., Pang, N., Foo, S. (2016), "When countries become the talking point in microblogs: Study on country hashtags in Twitter", First Monday, Vol. 21, No. 1.

34. Rodriguez, N. S. (2017), "\# FIFAputos: A Twitter Textual Analysis Over "Puto" at the 2014 World Cup", Communication \& Sport, Vol. 5, No. 6, pp. 712-731.

35. Rzeszewski, M. (2015), "Cyberpejzaż miasta w trakcie megawydarzenia: Poznań, Euro 2012 i Twitter", Studia Regionalne i Lokalne, Vol. 1, pp. 123-137.

36. Sevin, H. E. (2013), "Places going viral: Twitter usage patterns in destination marketing and place branding", Journal of Place Management and development, Vol. 6, No. 3, pp. 227239. 
37. Sevin, H. E. (2014), "Understanding cities through city brands: City branding as a social and semantic network", Cities, Vol. 38, pp. 47-56.

38. Shimada, K., Inove, S., Maeda, H., Endo, T. (2011), "Analyzing tourism information on Twitter for a local city", in 2011 First ACIS International Symposium on Software and Network Engineering, Seoul, South Korea, IEEE, pp. 61-66.

39. Sotiriadis, M. D., Van Zyl, C. (2013), "Electronic word-of-mouth and online reviews in tourism services: the use of Twitter by tourists", Electronic Commerce Research, Vol. 13, No. 1, pp. 103-124.

40. Strategic Direction Volume (2014), "Follow the leaders!: How Twitter is transforming destination marketing", Strategic Direction Volume, Vol. 30, No. 1, pp. 26-28.

41. Takahashi, K., Kato, D., Endo, M., Araki, T., Hirota, M., Ishikawa, H. (2017), "Analyzing Travel Behavior Using Multi-Label Classification from Twitter", in Proceedings of the 9th International Conference on Management of Digital EcoSystems, Bangkok, Thailand, ACM, pp. 50-56.

42. Tenkanen, H., Di Minin, E., Heikinheimo, V., Hausmann, A., Herbst, M., Kajala, L., Toivonen, T. (2017), "Instagram, Flickr, or Twitter: Assessing the usability of social media data for visitor monitoring in protected areas", Scientific reports, Vol. 7, No. 1.

43. Van Canneyt, S., Schockaert, S., Dhoedt, B. (2013), "Discovering and characterizing places of interest using flickr and Twitter", International Journal on Semantic Web and Information Systems (IJSWIS), Vol. 9, No. 3, pp. 77-104.

44. Wen, W., Clark, M., Kang, B., Fine, M. (2016), "The use of sina weibo and Twitter by international luxury hotels", Tourism Culture \& Communication, Vol. 16, No. 3, pp. 137-145.

45. Williams, N. L., Inversini, A., Buhalis, D., Ferdinand, N. (2015), "Community crosstalk: an exploratory analysis of destination and festival eWOM on Twitter" Journal of Marketing Management, Vol. 31, No. 9-10, pp. 1113-1140.

46. Zafiropoulos, K., Antoniadis, K., Vrana, V. (2017), "Community characteristics in tourism Twitter accounts of European countries", in Sigala, M., Gretzel, U. (Eds.), Advances in Social Media for Travel, Tourism and Hospitality, Routledge, pp. $311-321$. 


\section{About the authors}

Tamara Ćurlin is a Teaching Assistant and a Ph.D. student at the Faculty of Economics and Business, University of Zagreb, Department of Informatics. She received her BSC and MSc degrees from the Faculty of Economics and Business, University of Zagreb. She is teaching Informatics and Enterprise Information Systems courses exercises. Her current research interests include Information Technologies in Tourism, Mobile Technologies, Knowledge management, and Information management. The author can be contacted at tcurlin@efzg.hr.

Bozidar Jakovic, Ph.D., is an Assistant Professor and currently Vice Dean at Faculty of Economics \& Business, University of Zagreb, Croatia. He received his Ph.D., MSc and BSC degrees from the Faculty of Economics and Business, University of Zagreb. Also, he is an author of numerous internationally reviewed articles in journals including Acta Turistica, WSEAS Transactions on Information Science \& Applications, International Journal of Applied Mathematics and Informatics, Journal of International Scientific Publications: "Economy \& Business, Zbornik Ekonomskog fakulteta $\cup$ Zagrebu. His current research interests include Electronic Business, Web services, Web 2.0 technologies, Mobile technologies, Mobile applications, Document management, Elearning, Knowledge management, and Information management. He is actively engaged in a number of scientific projects. The author can be contacted at bjakovic@efzg.hr.

Assistant Professor Ivan Miloloža, Ph.D. graduated from the Faculty of Economics and Business in Zagreb and received a Ph.D. at the Faculty of Economics in Osijek in 2015. He lived and worked abroad in the period from 1983 to 1986 (Argentina and the Netherlands). Since 1986, he has been employed by Munja, the only Croatian battery manufacturer, where he has performed virtually all management functions and is currently the CEO of the Board (since 1999). He is Assistant Professor at the Department of Dental Medicine and Health, Dean for Institutional Cooperation and Development and Chair of the Department of History of Medicine and Social Sciences. He has performed many social functions in various state bodies, associations, and banks, and was a participant and guest lecturer at numerous domestic and foreign faculties and international conferences. The author can be contacted at ivan.miloloza@fdmz.hr. 